\title{
DÜBLIN
}

Technological University Dublin

ARROW@TU Dublin

\section{Towards a Pedagogy of Intergenerational Learning}

Anne Fitzpatrick

Technological University Dublin, anne.fitzpatrick@tudublin.ie

Follow this and additional works at: https://arrow.tudublin.ie/aaschsslbk

Part of the Sociology Commons

\section{Recommended Citation}

Fitzpatrick, A. (2019) Towards a Pedagogy of Intergenerational Learning in Intergenerational learning in Practice : Together Old and Young, Kernan \& Cortellesi (eds) London, Routledge 2019.

This Book Chapter is brought to you for free and open access by the Social Sciences at ARROW@TU Dublin. It has been accepted for inclusion in Books/Book chapters by an authorized administrator of ARROW@TU Dublin.

For more information, please contact arrow.admin@tudublin.ie, aisling.coyne@tudublin.ie, gerard.connolly@tudublin.ie.

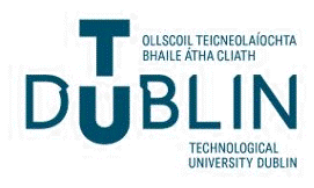




\title{
Towards a pedagogy of intergenerational learning
}

\author{
Anne Fitzpatrick
}

\section{Introduction}

Intergenerational learning (IGL) as a concept is as old as humankind and predates any type of formal education. It typically involved the informal transmission of knowledge, skills and values in multigenerational families as part of daily living (Hoff, 2007). This form of IGL only began to decline with the introduction of formal schooling and the separation of family life and work life. Over time, ideas about learning and education adapted to these changes until learning, at least in the public arena, began to be associated with formal educational institutions and only for children and young people (Hager \& Halliday, 2007). This was despite the extensive evidence of learning outside school, including IGL, that continued to play a significant role in the lives of children and adults, for example in the areas of cookery, arts, crafts and trades. However, IGL emerged as an area of interest in education, policy and academic research only in the late twentieth century (Bottery, 2016) and in this context has been defined as 'the way people of all ages can learn together and from each other' (EMIL, 2014, p. 1).

The promise that IGL can deliver meaningful and transformative learning environments for both young and old is now widely promoted at research, policy and practice levels. This is occurring in a context in which educational models that can respond to rapid and fast paced changes in twenty-first society are being proposed (ENIL, 2011; Findsen \& Formosa, 2011). The literature on IGL poses philosophical questions for consideration when imagining creative learning environments for 
now and into the future: could and should IGL be considered to offer opportunities for new models of educational practice? Could IGL extend or challenge contemporary ideas in educational thinking and practice? And, linked to this, how can IGL create opportunities for what could be considered a fundamental aspiration of education - to be transformative and to lead to profound change for individuals and communities (Sánchez et al., 2018; Schmidt-Hertha et al., 2015; Cabanillas, 2011; Mezirow, 1991; Freire, 1974)?

These questions form the basis of this chapter, which explores the promise of IGL as a distinct pedagogical approach. While the role of grandparents and other older people in the learning and development of young children (which happens organically in families and communities) is acknowledged, the focus in this chapter is on IGL in services for young and old. The approach adopted is to unpack selected and well-regarded contemporary educational theories influential in the field of early childhood pedagogy and learning and development in later life. Drawing on the literature the chapter will interrogate if, and how, IGL can enrich and reimagine the learning opportunities and choices for all people, including young children and older adults. In the final part of the chapter some critical perspectives on IGL as a pedagogical approach will be presented.

Let us first consider the current place of IGL in early years and elder care practice.

A fresh hope is astir. From many quarters comes the call to a new kind of education with its initial assumption affirming that education is life - not merely preparation for an unknown kind of future living ... The whole of life is learning, therefore education can have no endings.

(Lindeman, 1926, p. 6)

\section{IGL in early years and elder care settings - the evidence base}

To date, much IGL practice in early years and elder care settings has happened on an ad-hoc basis and usually without a strong basis in educational research, resulting in limited understanding of how 
generations learn together (Pinto, 2011; Withnall, 2017). There are a number of reasons to explain this, including the fact that IGL is a multidisciplinary and multisectoral activity occurring in a wide range of contexts such as preschools, afterschool services, day centres for older persons, care homes and community centres. This has made it difficult to build a strong knowledge base. Furthermore, theoretical underpinnings for IGL are at an early stage of development: to borrow a term from VanderVen, 'the road to intergenerational theory is under construction' (VanderVen, 2011). Kuehne and Melville (2014) in a study of IGL projects over a ten-year period identified more than 15 theoretical approaches underpinning a study of IGL practices (many blending a number of theories) but no evidence of a uniquely intergenerational theory. IGL, as an explicit approach, is not evident in well-regarded early years curricula of the Western World, such as High/Scope (Hohman \& Weikart, 2002), Reggio Emilia (Edwards et al., 1998) or Te Whariki (New Zealand Ministry of Education, 2017). Neither is it well established in recent policy on adult education (Borkowsky, 2013). (See also Chapter 1 for more information about the status of IGL in research, policy and practice.) Crucially, however, IGL practice brings to life key concepts of recent research on learning and development that apply to both young children and older people, which are encapsulated in Bruner's broad definition of human learning as 'participatory, proactive, communal, collaborative and given over to constructing meanings rather than receiving them' (Bruner, 1996, p. 84).

Before elaborating on the relevance of these and other concepts for IGL as a pedagogical approach, it is important to present key ideas about IGL as a learning approach as discussed in the literature.

\section{Key ideas about IGL as a learning approach}

The European Network of Intergenerational Learning (ENIL) has defined IGL as a learning partnership based on reciprocity and mutuality that involves different age groups working together to gain knowledge, skills and values (ENIL, 2011). Successful IGL fulfils ageappropriate developmental needs of children and adults, is relational and reciprocal and draws on the strengths and assets of each generation (Kaplan, 2001). In this way, intergenerational learning draws together 
commonalities in learning for young and old and moves away from a separatist conceptualisation of pedagogy, andragogy (adult learning) and the emerging proposal of geragogy (older adult learning) (Kern 2015; Schmidt-Hertha et al., 2015; Knowles, 1984).

While there remains a lack of critical research literature on IGL both as a learning and a curricular approach, a number of ideas relevant to learning and development and central to the practice of IGL can be identified in the available literature. IGL as a learning approach creates opportunities for:

- Promoting positive views of children and older people as equal in status with each having a strong capacity for agency and autonomy;

- Socially constructed learning through ongoing, active and collaborative relationships in an authentic cultural context, where participants learn together, from each other and about each other;

- Lifelong and lifewide learning with opportunities for formal, nonformal and informal learning;

- Mobilising the resources of the community to enrich the learning of young and old.

(Hatton-Yeo, 2015; Kaplan \& Sanchez, 2014;

Kump \&Krašovec, 2014; Kuehne \& Melville, 2014; Jarrott, 2011; VanderVen, 2011; Sánchez et al., 2007)

An analysis by the TOY Consortium of both the academic and grey literature (specifically on IGL between young children and older people) identified five key goals of intergenerational learning and practice, which reflect the ideas outlined above. The TOY goals are: building and sustaining relationships; enhancing social cohesion in the community; facilitating older people as guardians of knowledge; recognising the role of grandparents in young children's lives and enriching the learning processes of young children and adults. These goals serve as guiding principles for the learning approach underpinning TOY (TOY Project Consortium, 2013a and 2013b) (see Chapter 1).

Recognising that all learning approaches are influenced by history, economics, political discourses as well as time and culturally specific views about childhood, older adulthood and learning, this central issuehow early childhood and old age are viewed - will now be addressed. 


\section{Views of childhood and older adulthood and how they relate to IGL as a learning approach}

Views of childhood in the Western World have been changing rapidly in the late twentieth century and early twenty-first century, resulting in significant changes to children's lives, including their role in society and ideas about how they should be educated (Alanen, 2014; Corsaro, 2018). The child is now typically viewed as a fully fledged citizen rather than a citizen in the making - a being and a becoming in contrast to the past when the child was seen simply as a becoming. This view of childhood supports children's right to participate fully in their own development through processes that enhance not only their learning and development, but also their well-being. Viewing the child as rich and powerful, and an active agent in all aspects of their lives also points to the importance of the role and visibility of children in their community and in society (Cohen \& Korintus, 2016; Malaguzzi, 1993). This perspective reflects the belief that children are not only members of a family and, perhaps, an early childhood education (ECE) service but, importantly, are also members of a wider world. Children's right to participate in the wider world also serves to avoid the possibility of placing borders on children's learning opportunities (Fleer, 2003). This resonates strongly with ideas of IGL as a learning approach including the notion that learning that takes place in informal, non-formal and formal settings is equally valued.

This view of the child as a fully fledged citizen and rights-holder also raises the question of children and responsibility: can and should young children also have responsibilities to contribute to the lives of others? Children as people with responsibilities are strongly evident in the history of society but these responsibilities have been declining steadily in the Western World as the focus on protection of children increases (Gill, 2007). Balancing the child's right to protection while simultaneously promoting his right to active participation, in what Trevarthen calls 'the innate endowment of all children for positive contribution to society' (Trevarthen, 2011, p. 175), is not generally a primary consideration in ECE policy and practice in the Western World.

The child who is involved in IGL is indeed an active, contributing and visible citizen in his community. He is contributing to his own well-being and development and that of the older adults with 
whom he interacts. Furthermore, through his interactions with older adults, he is becoming visible to a greater variety of people and in more diverse locations. Consequently, the argument that the child-centred focus of much ECE policy and practices can distance the child from the world and people of all ages is challenged. In fact, IGL gives life to the concept of 'child-embeddedness', which reflects the idea of the child growing as an active participant in the midst of society, rather than in an age-segregated artificial world (Fleer, 2003, p. 67).

The perception of older adults in society has similarly been changing in recent decades, with a new emphasis on older adults as not only beings but also becomings. Older adults are now seen to have the right to ongoing access to opportunities for education, service to the community, sharing knowledge and skills (United Nations Human Rights Office of the High Commissioner, 1991) and to contribute their social, cultural and educational knowledge to a learning society (Madrid International Plan of Action on Ageing, 2002) (see Chapter 2 for further discussion on changing views of older adulthood). IGL practice offers wide-ranging learning and development opportunities for older adults, as well as diverse relationships and environments in which to share their experience, wisdom and cultural capital. As a result, both children and older adults can become active agents, not only in their own lives, but also in contributing to the lives of others, thus becoming more valued and more visible in their communities (Biggs \& Carr, 2015; Nimmo, 2008).

The ways in which learning is mediated through interactions in different social and cultural contexts have long been valued in illuminating learning processes. These ideas, which form the basis of the socio-cultural approach, strongly resonate with IGL and will now be discussed.

\section{The significance of socio-cultural perspectives for intergenerational learning}

The emergence of the broad paradigm of socio-cultural theory marked a watershed in the understanding of how children learn and develop, as well as reflecting new conceptions of the child. Theories of adult learning were also strongly influenced by the emerging socio-cultural perspective. Learning and development were no longer framed within an individualistic, normative developmental paradigm, and by the end 
of the twentieth century, socio-cultural theories dominated the research literature (Bruner, 1996; Qvortrup, 1994; Rogoff, 1994; Malaguzzi, 1998; Bronfenbrenner, 1979; Vygotsky, 1978). Simply put, socio-cultural theory proposed that development and learning occurs in the context of children's communities with educators (and more knowledgeable others), scaffolding and transforming learning in response to children's prior understandings. The early twenty-first century has seen greater emphasis placed on the dynamic and bidirectional nature of children's learning with, for example, children and adults, through their interactions, influencing each other (Hayes et al., 2017). IGL practice strongly supports theories of active and meaningful learning derived from a sociocultural perspective of learning. Two key constructs associated with the socio-cultural perspective will now be analysed with reference to their applicability to IGL: (1) the importance of relationships in learning and development, and (2) learning as an active and collaborative process.

\section{The importance of relationships in learning and development}

Strong evidence exists in the research literature of the important role played by relationships and interactions in children's learning and development (Trevarthen, 2011; Rogoff, 1998; Bronfenbrenner, 1979; Vygotsky, 1978). Both Bruner and Rogoff suggest that learning and development is embedded in the context of social relationships (Bruner, 1996; Rogoff, 1998). Bronfenbrenner argues that participating in progressively more complex patterns of reciprocal activity with a person to whom one has developed a strong and enduring emotional attachment is central to learning and development (Bronfenbrenner, 1979). Magaluzzi, proposed a pedagogy of relationships as a central principle of the Reggio Emilia approach that he founded (Cagliari et al., 2016) and a relational pedagogy underpins the core principles of Te Whariki (Papatheodorou \& Moyles, 2009). The power of everyday interactions in everyday contexts is now considered central to an approach that emphasises the educative value of caring relationships in what Hayes et al. term a 'nurturing pedagogy' (Hayes et al., 2017, p. 128).

Through IGL, children have opportunities to form relationships with older people of mixed ages, abilities, cultures and experiences that may 
be quite different to the relationships typically experienced within the ECE service. These relationships have the potential to provide a solid foundation for the relational dimensions of learning that underpin socio-cultural learning theories. Children who experience warm, responsive, playful relationships in cross-generational exchanges with older adults will benefit socially, emotionally and intellectually (NSCDC, 2004). The enriching power of everyday caring interactions in the ordinariness of everyday contexts (which could describe many typical IGL experiences) should not be underestimated for their contribution to the learning of young children (Hayes et al., 2017; Van Laere et al., 2012). See Chapters 4, 9 and 13 for illustrations of these experiences. The recognition of the value of caring as part of the educative process highlights the potential of IGL in ECE practice (Dalli, 2003). Critically, the developmental role of the interpersonal and relational aspects of ECE in promoting intersubjectivity and soft skills, such as empathy, has been widely acknowledged as important (Hayes et al., 2017; Siraj-Blatchford, 2009; Bruner, 1996).

The benefits of nurturing relationships for the well-being of older adults have also been identified (TILDA, 2018). Through playful, responsive interactions, older adults often have the opportunity to replay successful caring roles, renew positive emotions and reinforce meaning in their lives (Davis et al., 2002). The resulting sense of fulfilment, drawing on a wellspring of knowledge, skill and experience, acknowledges the link between cognition and emotion in supporting the older learners' ongoing development (Richards \& Hatch, 2011). The transformative nature of relationships (and relationships are central to IGL) has therefore, significant potential to positively impact on the learning and development of both young and old.

\section{Learning as an active, agentic and collaborative process}

The key role of collaboration in learning builds on the ideas of the social context of learning and the social construction of meaning and highlights the importance of shared activities leading to shared understandings (Trevarthen, 2011; Rogoff, 1998; Bruner, 1996). It also highlights the importance of the active role of the learners who equally 
influence the direction, timing and outcome of the activity which are key elements of collaborative learning (Rogoff, 1994; Vygotsky, 1978; Dewey, 1966). In arguing that learning occurs as people participate in shared activities with others, with each playing active but asymmetrical roles, Rogoff challenges the notion of one-sided learning and argues from the perspective of a theory of learning as participation embodied in a community of learning. One-sided ideas of learning suggest that the learning occurs through the transmission of knowledge from experts or the acquisition of knowledge by novices with the learner in a passive role. Participation and communities of learning theory enable the learner to gain knowledge as they collaborate with other children and adults through shared activities (Rogoff, 1994). High quality ECE curricula in the Western World are typically based on socio-cultural theories of learning, with their emphasis on active, collaborative learning.

IGL builds on these approaches by offering different possibilities than those typically available within the ECE centre. Collaborative learning through shared activities with people older than the adults they usually interact with, and in settings that they may not be familiar with (care homes, day centres) may lead to new types of shared understandings what Bruner refers to as the ability to read others' minds and thereby refine one's thinking (Bruner, 1996). Children and older people can actively and equally contribute ideas, intuition, energy, wisdom, skills and knowledge to the learning experiences. Opportunities for older adults and children to work together as expert (older adult) and novice (child) and vice versa to develop shared understandings and ideas, can lead to improved cognitive outcomes for all. Furthermore, through creating rich learning environments for collaborative learning, IGL opens up the possibilities for creating communities of practice. Communities of practice have been in existence as long as human beings have learned together, for example, a tribe learning to survive. However, the term 'community of practice' as a concept associated with situated learning theory was developed by Lave and Wenger (1991) and has been informed by socio-cultural theory. Lave and Wenger's key insight was the idea that knowledge, and, therefore, learning, was embedded in cultural practices so that the community can be seen as a living curriculum for each participant. Educators, then, should support learners to become embedded in authentic contexts in which they can 'do' the knowledge that is desired (Hoadley, 2012). 
IGL practice helps to create authentic contexts by introducing children and older adults to persons of different ages in different environments with all ages following their interests. A defining feature of IGL - embodied in the concept of a community of practice - is the fact that it places equal emphasis on learning together, learning from each other and learning about each other, with the central focus being on the nature of the interaction in the learning process (Sánchez et al., 2018).

Ideas about young and old as beings and becomings and the value of a wide range of environments to facilitate collaborative learning point to the importance of considering learning from a lifelong and a lifewide perspective.

\section{Lifelong and lifewide learning}

Lifelong and lifewide concepts of adult learning emerged strongly in the Western World in the 1990's to denote all learning that takes place over the life course and across all contexts of a person's life (Jarvis, 2008). It is broad-based, eclectic, integrated with daily life tasks and holistic. It is also distinct from formal education where the learning content is typically structured in subject-based knowledge and defined by State sponsored bodies.

Lifelong and lifewide learning acknowledge that, for most people, formal learning represents a very short part of their lifelong learning and development. These concepts also reflect Erikson's lifespan approach to human development, through which adults continue to learn in nonformal and informal environments (Erikson, 1980) (see also Chapter 2). As these concepts were taking root, ideas about IGL were also emerging, creating, in theory at least, a synergy and an understanding of IGL as an important form of lifelong learning (Tuijnman \& Boström, 2002).

It could be argued that, in a world where knowledge and skills rapidly become obsolete, lifelong learning is becoming increasingly relevant. Individuals need to continuously update knowledge and competence and, therefore, opportunities outside of and beyond the formal education system are increasingly important (Jackson, 2011).

Lifewide learning, which is a development of the lifelong concept, highlights the fact that learning can take place across the full range of life experiences at any stage of life and values the contribution of 'people 
who are not trained, paid or acknowledged as teachers' (Boström, 2003, p. 5). The importance of lifewide learning has long been acknowledged in the field of education with Dewey, the father of experiential learning, playing a central role in linking education, democracy, experience and society. Dewey argued that education, to be effective in preparing people for life, should relate much more closely to real life. In planning educational experiences then, it is vital to first understand the nature of human experience (Dewey, 1966). This vision of education is based on the idea that education is not divorced from experience, and learning is not confined to educational institutions. Therefore, learning can, and does, take place in the unstructured and dynamic interactions of ordinary life in different groups and communities, in what could be termed the curriculum of ordinary life. Learning happens through capitalising on the resources and assets of the lived experience of individuals embedded in everyday life, activities and conversations. These tenets resonate strongly with principles underpinning IGL, including the importance of non-formal and informal learning for people of all ages, which can create resources that add value to the lives of individuals and create stronger communities (Butts, 2007) (see Chapters 7, 8, 10 and 12). Kernan and van Oudenhoven (2010), in what they term the golden triangle of formal, informal and non-formal approaches, emphasise the importance of linkages between informal, non-formal and formal ECE, so that they can support and reinforce each other and create new possibilities for learning. These ideas about learning point to the important role the community plays in learning and development.

\section{The community as a locus and resource for learning}

Harnessing the resources of the community to improve the well-being and life chances of young and old is a complex yet valuable task. It requires the efforts of all segments of society, not just formal services such as ECE, and supports the adage that it takes a village to raise a child. Rogoff's research with Mayan and Maori children demonstrates the breadth of knowledge and skills that are taught and learned in communities (Rogoff, 2003). Trevarthen argues for a mixed-age community, stating that the child needs 'a responsive community of companions of 
all ages' (Trevarthen, 2011, p. 188). Hayes et al. (2017) caution against distancing children from society in an effort to enhance their learning and development and suggest that making effective links with children's communities is an important dimension of ECE practice. Exploring the resources of the community to create learning opportunities for young children is identified as important in the learning frameworks of High/ Scope, Reggio Emilia and Te Whariki. However, most child development research focuses on child, family and school variables with little research conducted on the impact of community-level variables and how informal learning in the community extends the learning opportunities offered by formal ECE services (Goldfeld et al., 2015).

Similarly, little research has been undertaken on the community dimension of learning in later life, despite the fact that learning for older people typically occurs there (Fragoso, 2015; Gallagher \& Fitzpatrick, 2018). Research into the role of the community in supporting learning, which is largely informal and non-formal in approach, would, if combined with research into formal educational processes, provide a more complete understanding of learning for both young and old.

An IGL approach, with its community focus, could serve to develop educational spaces that are more diverse and versatile than the formal, centre-based ECE service and adult learning settings. Such spaces could offer opportunities for children to 'play actively central roles, along with their elders and other companions, in learning and extending the ways of their communities' (Rogoff, 2003, pp. 284-285) while enhancing the agency and visibility of young and old. This fits with the concept of place-based learning, where the local community and environment is the starting point for hands-on, real-world learning experiences, facilitating interactions between different social and age groups. In this way, placebased learning can also contribute to the enhancement and invigoration of the community (Cohen \& Ronning, 2014). Valuing the community as a locus for learning also fits with the idea of Intergenerational Contact Zones. These zones serve to create community settings that welcome age- and generation-diverse populations, provide opportunities for meaningful intergenerational engagement, which can simultaneously enrich community life (Kaplan et al., 2016).

Figure 3.1 below summarises the proposed framework for IGL incorporating the operating concepts just discussed: importance of relationships in learning and development; learning as active, agentic and 


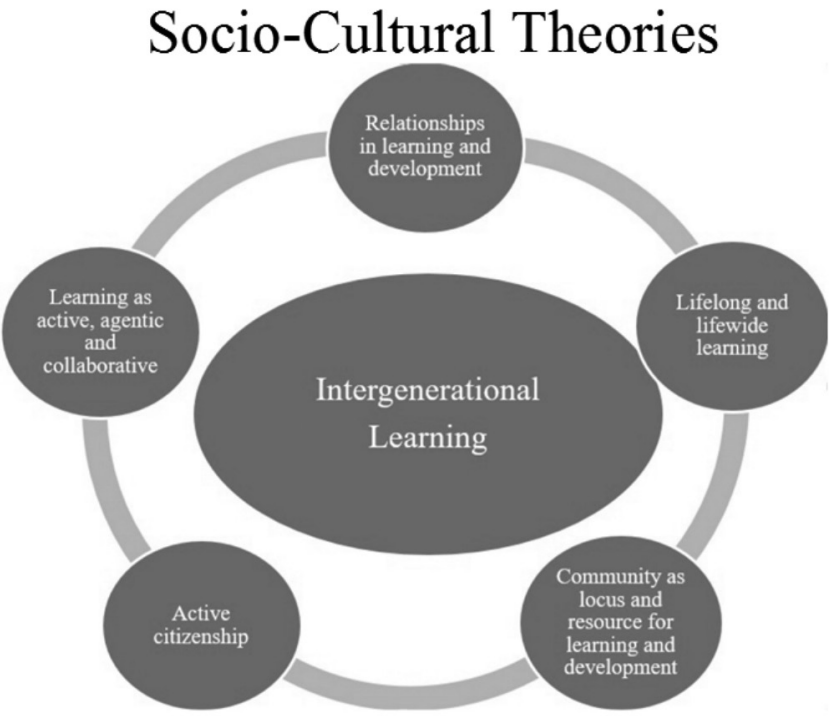

Figure 3.I Concepts underpinning IGL as a learning approach

Source: Fitzpatrick (2019)

collaborative; learning as both a lifelong and a lifewide endeavour and the community as a valuable locus and resource for learning.

\section{Concluding reflections on IGL and the future of education: some critical questions}

Widening learning spaces raises many questions, including what do we as a society want for young and old, what is the purpose and meaning of education and what role can education play in achieving a better society? IGL has much to offer in considering these essentially philosophical questions. Bronfenbrenner has suggested that a sustainable society relies on citizens who 'have learned the sensitivities, motivations and the skills involved in assisting and caring for other human beings', an idea that fits well with IGL (Bronfenbrenner, 1979, p. 53). Ideas emerging from the reconceptualist movement in ECE, which proposes a new educational discourse, highlight the values of democracy, co-operation, solidarity, wonder and surprise, in place of the strong instrumentality of much traditional ECE with its focus on outcomes. These ideas about 
learning and ECE services offer exciting new possibilities to reflect on contemporary views of the child in society and the role of ECE services in empowering children, older people and communities (Dahlberg et al., 2013; Urban, 2015).

The strengths of IGL as a pedagogical approach have been robustly argued in the literature reviewed in this chapter. However, a number of questions and challenges remain. To conclude the chapter, four of these challenges are identified and strategies to address them described.

Intergenerational learning as a pedagogical approach requires further research: Critical, theoretical perspectives based on empirical research into the benefits of IGL and how they 'happen' are almost non-existent. This is particularly true of research on IGL in promoting learning for the participants of all ages. The evidence that does exist focuses mainly on IGL as a strategy addressing social issues such as social isolation and promoting citizenship. As a consequence, IGL has not been adequately investigated as a learning and teaching strategy nor has the knowledge, skills and experiences of young and old participating in IGL programmes been systematically studied. Interdisciplinary and longitudinal research is required on all aspects of the IGL process, including, for example, research on the dynamics of the interactions and their role in the development of agency.

Synergies need to be identified between formal curricula and IGL to ensure its sustainability as a learning approach: For IGL to be valued and to become a sustainable approach across the ECE and older adults' sector, understanding of how IGL principles can facilitate the learning goals of ECE curricula and adult learning frameworks must be clearly articulated and argued. Robust research evidence and policy commitment is required to develop an IGL approach that assures the potential, opportunities and rights of all participants and ensures equality of development opportunities for young and old, thereby avoiding the possibility of one generation being privileged over another. Furthermore, appropriate cross-disciplinary training and support of practitioners is essential if IGL is to be embedded as a pedagogical approach.

\section{The role of a 'champion' in implementing IGL as a pedagogical approach}

Implementing IGL practice is still largely an optional approach in ECE and older adults services and, therefore, may require courage, leadership 
and specific practical supports to succeed. Supports could include additional support in training and mentoring, identifying potential partners and appropriate spaces, complying with sector regulations and managing logistics. The question may then be asked - does IGL practice require a practitioner who can act as a champion and, if yes, does this limit the likelihood of IGL as an approach being mainstreamed?

Imagining a more expansive view of learning environments that includes IGL: Society's perception of what is valuable for young and old to learn and what is an appropriate environment in which to learn is a key challenge in promoting IGL as a learning approach. Lifelong learning beyond the school walls through mutually rewarding relationships and informal learning through shared spaces and shared activities is still not widely recognised as a valuable educational goal. Arguably, it is society's views of learning for young and old that could pose the greatest challenge to IGL as a pedagogical approach.

\section{References}

Alanen, L. (2014) Theorizing childhood. Childhood. 21 (1), 3-6.

Biggs, S. \& Carr, A. (2015) Age- and child-friendly cities and the promise of intergenerational space. Journal of Social Work Practice. 29 (1), 99-112.

Borkowsky, A. (2013) Monitoring adult learning policies: A theoretical framework and indicators. OECD Educational Working Papers, No. 88. Paris, OECD Publications.

Boström, A. (2003) Lifelong learning, intergenerational learning and social capital. From theory to practice. Stockholm, Institute of International Education.

Bottery, T. (2016) The future of intergenerational learning: Redefining the focus? Studia Paedagogica. 21 (2), 9-24.

Bronfenbrenner, U. (1979) The ecology of human development. Cambridge, Harvard University Press.

Bruner, J. (1996) The culture of education. Cambridge, Harvard University Press.

Butts, D. (2007) Intergenerational programs and social inclusion of the elderly. In: Sanchez, M. (ed.) Intergenerational programmes - Towards a society for all ages. Barcelona, The 'la Caixa' Foundation, pp. 92-108

Cabanillas, C. (2011) Intergenerational learning as an opportunity to generate new educational models. Journal of Intergenerational Relationships. 9 (2), 229-231.

Cagliari, P., Castagnetti, M., Giudici, C., Rinaldi, C., Vecchi, V. \& Moss, P. (eds.) (2016) Loris Malaguzzi and the Schools of Reggio Emilia. A Selection of his Writings and Speeches, 1945-1993. London, Routledge. 
Cohen, B. \& Korintus, M. (2016) Young children in their local communities. In: Farrell, A., Kagan, S.L. \& Tisdall, E.K.M. (eds.) The Sage handbook of early childhood research. New York, Sage Research Methods, pp. 55-70.

Cohen, B.J. \& Rønning, W. (2014) Place-based learning in early years services: approaches and examples from Norway and Scotland. In: Miller, L. \& Cameron, C. (eds). International perspectives in the early years. London, SAGE Publications, pp. 112-126.

Corsaro, W.A. (2018) Sociology of childhood. Fifth Edition. Thousand Oaks, SAGE Publications.

Dahlberg, G., Moss, P. \& Pence, A. (2013) Beyond quality in early childhood and care. London, Routledge.

Dalli, C. (2003) Professionalism in early childhood practice: Thinking through the debates. Paper presented to the 13th Annual Conference of the European Early Childhood Education Research Association (EECERA). Glasgow, Scotland.

Davis, L., Larkin, E. \& Graves, S. (2002) Intergenerational learning through play. International Journal of Early Childhood. 34 (2), 42-49.

Dewey, J. (1966) Democracy and education: An introduction to the philosophy of education. New York, Free Press.

Edwards, C., Gandini, L. \& Forman, G. (eds.) (1998) The hundred languages of children: The Reggio Emilia approach. Advanced reflections. Second Edition. Westport, Ablex Publishing.

Erikson, E.H. (1980) Identity and the life cycle. New York, W. Norton \& Co.

European Map of Intergenerational Learning (EMIL) (2014) What is intergenerational learning? Available from: http://www.emil-network.eu [Accessed 13 November 2018].

European Network of Intergenerational Learning (ENIL) (2011) Report on intergenerational learning and volunteering. Available from: http://www.enilnet. eu/Dossier_ENIL_EN2.pdf [Accessed 13 November 2018].

Findsen, B. \& Formosa, M. (2011) Lifelong learning in later life. Rotterdam, Sense Publishers.

Fleer, M. (2003) Early childhood education as an evolving 'community of practice' or as lived 'social reproduction': Researching the 'taken for granted'. Contemporary Issues in Early Childhood. 4 (1), 64-79.

Fragoso, A. (2015) Older adults as active learners in the community. In: Schmidt-Hertha, B., Krasovec, S.J. \& Formosa, M. (eds.) Learning across generations in Europe. Rotterdam, Sense Publishers, pp. 59-73.

Freire, P. (1974) Education for critical consciousness. London, Continuum.

Gallagher, C. \& Fitzpatrick, A. (2018) It's a win-win situation. Intergenerational learning in preschool and elder care settings: An Irish perspective. Journal of Intergenerational Relationships. 16 (1-2), 26-44.

Gill, T. (2007) No fear: Growing up in a risk averse society. London, Calouste Gulbenkian Foundation.

Goldfeld, S., Woolcock, G., Katz, I., Tanton, R., Brinkman, S., O’Connor, E., Mathews, T. \& Giles-Corti, B. (2015) Neighbourhood effects influencing early 
childhood development: conceptual model and trial measurement methodologies from the Kids in Communities study. Social Indicators Research: An International and Interdisciplinary Journal for Quality-of-Life Measurement. 120 (1), 197-212.

Hager, P. \& Halliday, J. (2007) Recovering informal learning: Wisdom, judgement and community. Dordrecht, Springer.

Hatton-Yeo, A. (2015) A personal reflection on the definitions of intergenerational practice. Journal of Intergenerational Relationships. 13 (3), 283-284.

Hayes, N., O’Toole, L. \& Halpenny, A. (2017) Introducing Bronfenbrenner A guide for practitioners and students in early years education. London, Routledge.

Hoadley, C. (2012) What is a community of practice and how can we support it? In: Jonassen, D. \& Land, S. (eds) Theoretical foundations of learning environments. Second Edition. New York, Routledge, pp. 287-300.

Hoff, A. (2007) Intergenerational learning as an adaptation strategy in aging knowledge societies. In: European Commission (ed.) Education, employment, Europe. Warsaw, National Contact Point for Research Programmes of the European Union, pp. 126-129.

Hohman, M. \& Weikart, D. (2002) Educating young children: Active learning practices for preschool and child care programs. Second Edition. Ypsilanti, HighScope Press.

Jackson, N.J. (ed.) (2011) Learning for a complex world: A lifewide concept of learning, education and personal development. Bloomington, Author House Publishing.

Jarvis, P. (2008) Democracy, lifelong learning and the learning society: Active citizenship in a late modern age. London, Routledge.

Jarrott, S. (2011) Where have we been and where are we going? Content analysis of evaluation research of intergenerational programs. Journal of Intergenerational Relationships. 9 (1), 37-52.

Kaplan, M. (2001) School-based intergenerational programs. Hamburg, UNESCO Institute of Education.

Kaplan, M., Thankg, L.L., Sanchez, M. \& Hoffman, J. (2016) An introduction to 'intergenerational contact zones'. Available from: https://aese.psu. edu/extension/intergenerational/articles/intergenerational-contact-zones. [Accessed 4 March 2019].

Kaplan, M., \& Sánchez, M. (2014) Intergenerational programmes. In: Harper, S. \& Hamblin, K. (eds), with Hoffman, J., Howse, K. \& Leeson, G. International handbook on ageing and public policy. Cheltenham, Edward Elgar Publishing, pp. 367-383.

Kern, D. (2015) Conceptual basis for learning: Frameworks for older adult learning. In: Schmidt-Hertha, B., Krasovec, S.J. \& Formosa, M. (eds) Learning across generations in Europe. Rotterdam, Sense Publishers, pp. 73-85.

Kernan, M. \& van Oudenhoven, N. (2010) Community-based early years services: The golden triangle of informal, non-formal and formal approaches. 
Available from: https://www.eurochild.org/fileadmin/public/02_Events/ 2010/MES/MES_Background_paper_Final_September2010.pdf [Accessed 23 May 2019].

Knowles, M. (1984) Andragogy in action. San Francisco, Jossey-Bass.

Kuehne, V. \& Melville, J. (2014) The state of our art: A review of theories used in intergenerational program research (2003-2014) and ways forward. Journal of Intergenerational Relationships. 12 (4), 317-346.

Kump, S. \& Krašovec, S.J. (2014) Intergenerational learning in different contexts. In: Schmidt-Hertha, B., Krasovec, J., \& Formosa, M. (eds.) Learning across generations in Europe. Rotterdam, Sense Publishers, pp. 167-177.

Lave, J. \& Wenger, E. (1991) Situated learning: Legitimate peripheral participation. New York, Cambridge University Press.

Lindeman, E.C. (1926) The meaning of adult education. New York, New Republic.

Madrid International Plan of Action on Ageing (2002) UN second world assembly on ageing. Available from: https://www.un.org/esa/socdev/documents/ageing/ MIPAA/political-declaration-en.pdf [Accessed 23 May 2019].

Malaguzzi, L. (1993) For an education based on relationships. Young Children. 49 (1), 9-12.

Malaguzzi, L. (1998) History, ideas, and basic philosophy: An interview with Lella Gandini. In: Edwards, C., Gandini, L. \& Forman, G. (eds) The hundred languages of children: The Reggio Emilia Approach. Advanced Reflections. Second Edition. Westport, Ablex Publishing, pp. 49-98.

Mezirow, J. (1991) Transformative dimensions of adult learning. San Francisco, Jossey-Bass.

National Scientific Council on the Developing Child (NSCDC) (2004) Young children develop in an environment of relationships. Available from: https:// developingchild.harvard.edu/wp-content/uploads/2004/04/Young-ChildrenDevelop-in-an-Environment-of-Relationships.pdf [Accessed 13 November 2018].

New Zealand Ministry of Education (2017) Te Whariki. Available from: https:// education.govt.nz/assets/Documents/Early-Childhood/ELS-Te-WharikiEarly-Childhood-Curriculum-ENG-Web.pdf [Accessed 23 May 2019].

Nimmo, J. (2008) Young children's access to real life: An examination of the growing boundaries between children in child care and adults in the community. Contemporary Issues in Early Childhood. 9 (1), 3-13.

Papatheodorou, T. \& Moyles, J. (2009) Learning together in the early years: Exploring relational pedagogy. Abingdon, Routledge.

Pinto, T. (2011) Why intergenerational learning is not an academic discipline yet? Journal of Intergenerational Relationships. 9, 117-119.

Qvortrup, J. (1994) Childhood matters: Social theory, practice and politics. Aldershot, Avebury.

Richards, M. \& Hatch, S. (2011) Good news about the ageing brain. British Medical Journal. Available from: doi:10.1136/bmj.d6288 